\title{
ECONOMIC AND LEGAL ASPECTS OF SUNFLOWER INSURANCE USING THE MODEL OF REGIONAL INDEX ${ }^{1}$
}

\author{
Todor Marković², Janko Veselinović ${ }^{3}$ Željko Kokot ${ }^{4}$
}

\begin{abstract}
Summary
The application of index insurance in agriculture is becoming more and more popular in the last few years, especially in developed countries. Index insurance of crops and fruits is based on data related to a particular administrative unit or region. The regional index represents the average yield or average revenue in a region that is the basis for calculating the premium and insurance compensation. In the case of sunflower production, one of the most frequent crops in the region of Kula municipality, the authors show the methodology of applying the analysed insurance. The main advantage of this insurance model can be the facts that there is no need to estimate the damage, as well as a drastic reduction in morale-hazard. This insurance model can be a significant alternative to classical insurance and its implementation should result in an increase in the number of insured and insured areas. Firstly, it is necessary to remove the potential legal dilemmas about the implementation of this insurance model in Serbia and to define more precisely some legal institutions in this area.
\end{abstract}

Key words: insurance, regional index, sunflower, damage assessment, moral hazard.

JEL: Q14, G22

1 The paper is a result of the research conducted within the project III-46006 of the Ministry of Education, Science and Technological Development of the Republic of Serbia titled Sustainable agriculture and rural development in order to achieve strategic goals Republic of Serbia in the Danube region and the project No. 47024 of the Ministry of Education and Science titled Social relations of Serbs and Croats, national identity and minority rights from the aspect of European integration.

2 Todor Marković, PhD, associate professor, University of Novi Sad, Faculty of Agriculture, Department of Agricultural Economics and Rural Sociology, Dositej Obradovic Square 8, 21000 Novi Sad, Serbia, Phone: +381 2148534 19, E-mail: todor.markovic@polj.edu.rs

3 Janko Veselinović, PhD, associate professor, University of Novi Sad, Faculty of Agriculture, Department of Agricultural Economics and Rural Sociology, Dositej Obradovic Square 8, 21000 Novi Sad, Serbia, Phone: +381 2148533 78, E-mail: veselinovic.janko@gmail.com

4 Željko Kokot M.Sc, PhD student, University of Novi Sad, Faculty of Agriculture, Department of Agricultural Economics and Rural Sociology, Dositej Obradovic Square 8, 21000 Novi Sad, Serbia, Tel: +381 6430552 92, E-mail: zeljko.kokot5@gmail.com

EP 2018 (65) 1 (215-228) 


\section{Introduction}

In the recent years, we have witnessed accelerated climate change around the world. Modern agriculture world is facing many challenges and opportunities for development. It concerns the industrialization of agriculture and processes in the field of biotechnology, changing climatic conditions, opportunities, creating the era of information economy and globalization (Belei, 2017).

Unpredictable climatic events and natural disasters have always influenced to a large extent on the lives of all people on our planet, as well as on various economic activities. Based on the research, it is estimated that even $70 \%$ of the world economy is conditioned by weather fluctuations (Jain, Foster, 2000). Climate change projections indicate a major problem that will arise in the future (Fuhrer et al., 2006; Calanca, 2007). Based on this, it is necessary to use various measures to reduce the risk of various weather disasters, as well as the application of various risk management instruments (Bielza et al., 2007) and this issue, which at the same time represents the subject of research of the work itself, is more and more relevant in modern agroeconomic literature. As a separate issue, due to the uncontested climate changes, there is a redefinition of the role of the state and local governments in terms of legal regulation and the direct or indirect legal and economic guidance of flows in insurance regarding weather-related fluctuations.

Undoubtedly, the best possible way to manage risk in agricultural production is to insure crops and fruits. In the past, yield insurance systems were mainly considered, and this type of operation function effectively where obligatory insurance is stipulated or there are subsidies from the state (Prettenthaler et al., 2006). Since some of the traditional insurance models have shown several shortcomings, there has always been a need to develop new insurance models that hinder in the meantime. Depending on the criteria, crop and fruit insurance systems can be divided to different ways, and one of the most comprehensive divisions distinguishes insurance against yield loss, success indicators insurance, whole-farm insurance, and index (parametric) insurance (Marković, 2013). Of all the listed systems, index insurance represents a group of the latest insurance models, and its wider application can certainly be expected in the near future. This group includes insurance based on the regional index and weather derivatives. Insurance based on the regional index represents an alternative to traditional multi risk crop insurance, and as a parameter, this type of insurance takes the average achieved yield or the average realized market revenue in a certain region (Marković et al., 2016). The latter type of insurance is based on the product of the average yield and the price for a particular region, and the characteristic of this type of insurance is that the average revenue per area unit in a certain administrative region (district, municipality, etc.) is used as the basis for covering the risk (Dismukes et al., 2013). In this way, protection against loss of revenue due to fall in yield, reduction in purchase prices or a combination of both of these factors is ensured, but this model will be further discussed in another study. 
In this paper, special attention is paid to insurance based on the regional yield. In this model, insurance premiums are realized if the average regional yield is below the longawaited average yield (Skees et al., 1997), whereby it is necessary to check (prove) whether the total insurance payment is conditional on changes in yield. This type of insurance was created in the middle of the last century as an alternative to insuring individual yields, with the aim of reducing moral hazard and negative selection (Halcrow, 1949), but much more attention was devoted to it in the 1990s when it returned to the focus of scientific interests (Miranda, 1991). The condition for the implementation of this concept is the formation of geographic regions, which are homogeneous in terms of climate. This assumes that all agricultural producers in the region pay the same insurance premium, and in the occurrence of the insured case, they will be compensated also in the equal amounts (Ebneth, 2003). The significant advantage of this model in comparison to the classical ones is reflected in the reduction of moral hazard, since individual insurers have no influence on the amount of the regional index achieved, nor on the level of indemnity (Chambers, Quiggin, 2002). Also, insurance based on the level of the regional index is less susceptible to asymmetric information, and it is not necessary to determine the expected yields and/or revenues for each individual farm (Deng et al., 2008). In addition, the aforementioned insurance model provides farmers with a better overall all risk protection in relation to some of the individual insurance (Schlieper, 1997). Among the other advantages of insurance based on the regional index, the elimination of negative selection, reduction of transaction costs, lower franchise and higher coverage level should be highlighted (Wolf, 1998; Ebneth 2003; Hirschauer, Mußhoff, 2008). It is also assumed that the amount of insurance premium per unit of capacity is lower than the amount of the premium in classical and indirect index insurance, which will be verified (proved) below. With this insurance system, several models can be used to determine the insurance premium amount. According to the model used by the World Bank, in a study dedicated to crop insurance in Senegal, the premium is calculated as the sum of the expected loss, the risk margin and administrative costs. Also, the premium can be calculated as the sum of the actuarial fair premium adjusted to the risk, and certain administrative and operational costs (Smith, Watts, 2009).

In Serbia, most insurance companies still apply mainly classical insurance systems for reduced yields, which are based on damage assessment, whereby farmers are insured from basic risks (hail, fire and lightning) and some other additional risks (storms, floods, spring frost). There are no modern insurance systems, although some empirical data indicate a real need for these models. Insurance based on the regional index is certainly one of those whose implementation in Serbia would be desirable. For these reasons, the aim of the research in this paper is to develop the theoretical basis and to present a practical example of insurance based on the regional index, whose characteristics are not well known to the domestic agroeconomic public.

In addition to the economic aspect, in order to fully understand this area, it is necessary to analyze the legal aspects of sunflower insurance using the regional index. Due to 
the lack of positive legislation in this area, but also because of the poor autonomous sources of rights, such as general business terms and conditions or contracts in this area, it is important to provide answers to some of the questions. The aim of this paper is to provide relevant answers concerning the legal framework and elements of the contract between the insured and the insurer, in this specific legal transaction. The subject of the legal analysis is two relationships, namely: the relationship between local self-government and the insured and relationship between the insured and the insurer. We have paid more attention to another relationship because it is purely legal in nature, while the relationship between local self-government and insured belongs mainly to the sphere of economic policy, which should certainly have its own legal frameworks. The aim of the paper was to come to a concrete example through a theoretical analysis, which can serve both legal theory and practice.

\section{Material and methods}

For the purpose of the research, data from the Statistical Office of the Republic of Serbia were used on average areas, achieved yields and realized sunflower production on the territory of Kula municipality. Data were analysed for a period of five years (2010-2014). On the example of the mentioned municipality, the model of insurance application based on the regional index is presented. When using this model, as a regional index, the average yield was used in the analysed period, and the insured area refers to the average area under sunflower in the observed region. The contracted value of certain crops per unit of yield was taken from the Product Exchange in Novi Sad. Assuming the achievement of a lower and higher yield than the average, a simulation of the application of the analysed insurance system is carried out, whereby the following parameters are calculated:

Guaranteed (insured) yield $\left(E_{v}\right)$ represents product of expected average municipality yield $\left(E_{d g}\right)$ and contract level of insured coverage expressed in \% $\left(D_{v}\right)$ :

$$
E_{v}=E_{d g} \cdot D_{v}
$$

Insurance sum per hectare $\left(S_{v e}\right)$ is calculated as a product of guaranteed (insured) yield $\left(E_{v}\right)$ and contract value per yield unit $\left(P_{p}\right)$ :

$$
S_{v e}=E_{v} \cdot P_{p}
$$

Total insurance sum $\left(\Sigma S_{v}\right)$ was obtained as a product of insurance sum per area unit $\left(S_{v e}\right)$ and total insured area $\left(F_{v}\right)$ :

$\sum S_{v}=S_{v e} \cdot F_{v}$

Further, possible loss amount that can be compensated by using analysed model as well as indemnity amount, are obtained by simulation. Realized loss $\left(V_{r}\right)$, expressed absolutely, represents coefficient of difference of insured (guarantee) $\left(E_{v}\right)$ and realized yield $\left(E_{r}\right)$, and insured yield $\left(E_{v}\right)$, and if multiplied with 100 the percentage amount will be obtained: 


$$
V_{r}=\frac{E_{v}-E_{r}}{E_{v}} \cdot 100
$$

Insurance indemnity $\left(\Sigma A_{v}\right)$ is obtained as a product of realized loss expressed in $\%\left(V_{r}\right)$ and total insurance sum $\left(\Sigma S_{v}\right)$ :

$\sum A_{v}=V_{r} \cdot \sum S_{v}$

On the other hand, insurance indemnity per area unit $\left(A_{v e}\right)$ can be obtained as a product of realized loss expressed in \% $\left(V_{r}\right)$ and insurance sum per hectare $\left(S_{v e}\right)$, but also as a product of difference of guaranteed (insured) yield $\left(E_{v}\right)$ and realized yield $\left(E_{r}\right)$, and product price $\left(P_{p}\right)$, according to the following formulas:

$A_{v e}=V_{r} \cdot S_{v e}$

$A_{v e}=\left(E_{v}-E_{r}\right) \cdot P_{p}$

Insurance premium per area unit $\left(K_{v e}\right)$ is calculated as a product of premium rate $\left(K_{f}\right)$ and insurance sum per area unit $\left(S_{v e}\right)$, provided that the premium rate is $4,6 \%$ (Carter et al., 2007):

$$
K_{v e}=K_{f} \cdot S_{v e}
$$

At the end, total insurance premium $\left(\Sigma K_{v}\right)$ is obtained as a product of insurance premium per hectare $\left(K_{v e}\right)$ and total insured area $\left(F_{v}\right)$ :

$$
\sum K_{v}=K_{v e} \cdot F_{v}
$$

Based on the previous mentioned calculations, obtained is amount of insurance cost, as well as total loss value in sunflower production, that can be compensated by applying analysed insurance model. Along with these economic considerations, the analysis of positive legal regulations and practices of insurance organizations in this area was done.

\section{Results and discussion}

On the territory of the studied Kula municipality one of the most frequent crops is sunflower, which is grown on the surface of 2,000 ha. Sunflower production is characterized by relatively large oscillations per year in terms of planted areas and total production (Table 1).

The cause of these parameters certainly is the occurrence of different production risks that sunflower producers face. Consequences of this are lower production, lower total revenues at the level of all agricultural producers within the observed municipality, and consequently the realization of weaker financial results per capacity unit. Since the risks in the agricultural sector are specific, management also requires specific models. 
Table 1. Sunflower production in Kula municipality (2010-2014)

\begin{tabular}{|c|c|c|c|c|c|}
\hline \multirow{2}{*}{ Parameter } & \multirow{2}{*}{$\begin{array}{l}\text { Average } \\
\text { (without }\end{array}$} & \multirow{2}{*}{$\begin{array}{c}\text { Variation } \\
\text { coefficient }(\%)\end{array}$} & \multicolumn{2}{|c|}{ Variation interval } & \multirow{2}{*}{$\begin{array}{c}\text { Change rate } \\
(\%)\end{array}$} \\
\hline & & & Minimum & Maximum & \\
\hline Area (ha) & exfregme) & 13,5 & 1.613 & 2.391 & $-9,37$ \\
\hline Yield (kg/ha) & 2.876 & 16,3 & 2.112 & 3.402 & 3,30 \\
\hline Production $(\mathrm{t})$ & 5.711 & 16,5 & 4.095 & 6.768 & $-6,37$ \\
\hline
\end{tabular}

Source: Authors based on Statistical Office of the Republic of Serbia

This paper analyses the model of insurance that includes insurance of yield loss in certain crops in the region. On a concrete case of sunflower production, an example of index insurance at the municipal level is given, within which protection from production losses is provided through a program of insurance and reinsurance against the consequences of all natural and climatic risks (drought, hail, flood, storm, cold, excessive precipitation etc.), which can lead to a significant reduction in yields and based on that market value of production. There are several key differences between micro-aspect insurances, that is, at the level of individual farmers and insurances, which are concluded on the so-called mezzo-level, that is, from the aspect of local selfgovernment (municipality).

Schema 1. Program for insurance of revenue loss in Serbia on mezzo-level

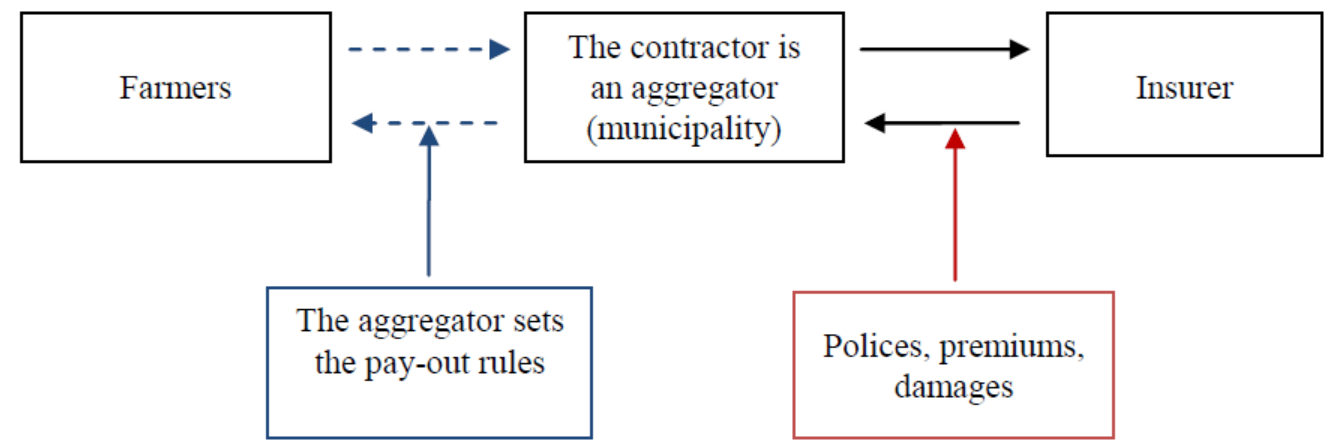

Source: www.europa-re.com

Differences are reflected in the fact that at the mezzo-level, local self-government, or more precisely, the municipality, appears in the function of the insurance contractor and the insured, whereby it is responsible for paying the entire insurance premium. The municipality should decide which agricultural producers want to insure, which crops will be the subject of insurance, and then to decide on the breadth of the protection program it wants to buy, i.e. the total area it wishes to insure, the level of insurance yield coverage, as well as the sum of insurance per area unit. If a yield achieved at the municipal level is below the agreed yield, the right to indemnity is obtained. It is calculated on the basis of the percentage of contract yield reduction. The yield insurance at the municipal level allows the conclusion of the guaranteed (insured) yield and yield coverage of at least $60 \%$, and at most $90 \%$ of the expected municipal yield. Below is 
the example of the functioning of this new insurance mechanism, i.e. an example of calculating insurance premiums in the case of a sunflower yield insurance contract, with a $15 \%$ reduction in the average municipal yield (Table 2 ).

In the five-year period at the level of the analysed municipality, without extreme values, the average yield of $2,876 \mathrm{~kg} / \mathrm{ha}$ is realized in sunflower production. The sunflower was cultivated on an area of 1,993 ha. Based on average data on areas and yields, using the formula in the method of paper, the values of guaranteed yield (1), insurance sum per area unit (2), and at the end of the total amount of insurance (3) were obtained. For 2016, certain yields are assumed that are lower and higher than the average yield. The lower yield option, using the formula (4) specified in the method of paper, assumes the realized losses of $24.34 \%$. On this basis, the insurance indemnity based on the formula (5) is made, with the payment amounting to RSD 40.3 million with the insured sunflower production, while in the option with higher yield, there is no compensation. Also, using the formulas (6) and (7), the amount of insurance indemnity per hectare is reached (20.230 RSD). Based on the formula (8) the amount of insurance premium per unit of capacity is $3,824 \mathrm{RSD}$. This is approximately the same, or even lower, compared to premiums in classical insurance (Marković, 2013), or below the level of premiums for indirect index insurance (Marković et al., 2013). Regardless of the realized yield, according to the formula (9), the insured persons have an obligation towards the insurer in the amount of 7,621,192 RSD, what is the total insurance premium at the level of the observed municipality.

Table 2. Calculation of insurance indemnity using model based on regional index

\begin{tabular}{|l|c|c|}
\hline & \multicolumn{2}{|c|}{ Sunflower } \\
\hline Average yield at the municipality level $\left(\boldsymbol{E}_{d g}\right)(\mathrm{kg} / \mathrm{ha})$ & 2.876 & 2.876 \\
\hline Contract level of insurance coverage $\left(\boldsymbol{D}_{v}\right)(\%)$ & 85 & 85 \\
\hline Guaranteed (insured) yield $\left(\boldsymbol{E}_{v}\right)(\mathrm{kg} / \mathrm{ha})$ & 2.445 & 2.445 \\
\hline Contract price $\left(\boldsymbol{P}_{p}\right)(\mathrm{RSD} / \mathrm{kg})$ & 34 & 34 \\
\hline Insurance sum per ha $\left(\boldsymbol{S}_{v e}\right)(\mathrm{RSD} / \mathrm{ha})$ & 83.130 & 83.130 \\
\hline Insured area $\left(\boldsymbol{F}_{v}\right)(\mathrm{ha})$ & 1.993 & 1.993 \\
\hline Total insurance sum $\left(\sum \boldsymbol{S}_{v}\right)(\mathrm{RSD})$ & 165.678 .090 & 165.678 .090 \\
\hline Realized yield in $2016\left(\boldsymbol{E}_{\boldsymbol{r}}\right)(\mathrm{kg})$ & 1.850 & 3.700 \\
\hline Realized loss & 0,24335 & 0 \\
\hline Realized loss $\left(\boldsymbol{V}_{\boldsymbol{r}}\right)(\%)$ & 24,34 & 0 \\
\hline Insurance indemnity $\left(\sum \boldsymbol{A}_{v}\right)(\mathrm{RSD})$ & 40.317 .763 & 0 \\
\hline Insurance indemnity $\left(\boldsymbol{A}_{v e}\right)(\mathrm{RSD} / \mathrm{ha})$ & 20.230 & 0 \\
\hline Insurance premium amount $\left(\boldsymbol{K}_{v e}\right)(\mathrm{RSD} / \mathrm{ha})$ & 3.824 & 3.824 \\
\hline Insurance premium amount $\left(\sum \boldsymbol{K}_{v}\right)(\mathrm{RSD})$ & 7.621 .192 & 7.621 .192 \\
\hline
\end{tabular}

Source: Authors' calculation 
Total insurance indemnity is directly caused by changes in yield. With increasing of yields, it decreases and at a certain point it is equal to zero, i.e. there will not be insurance indemnity if the average realized yield at the level of the analysed region (municipality) reaches the amount of the guaranteed yield. In cases with $85 \%$ coverage level, the guaranteed yield of sunflower would be $2,445 \mathrm{~kg} / \mathrm{ha}$. Graph 1 shows the movement of potential insurance indemnities, depending on the movement of the realized yield.

Similar observations apply to other coverage levels. The basic differences are reflected in the amount of the guaranteed yield, the amount of the total insurance sum and the amount of insurance indemnity. The lower the coverage level, the mentioned parameters have less value. Regardless of the defined level, this model insures all yields lower than the insured (guaranteed) yield, based on the concluded contract between the insured and the insurer.

Graph 1. Movement of insurance indemnities at the level of the analysed municipality

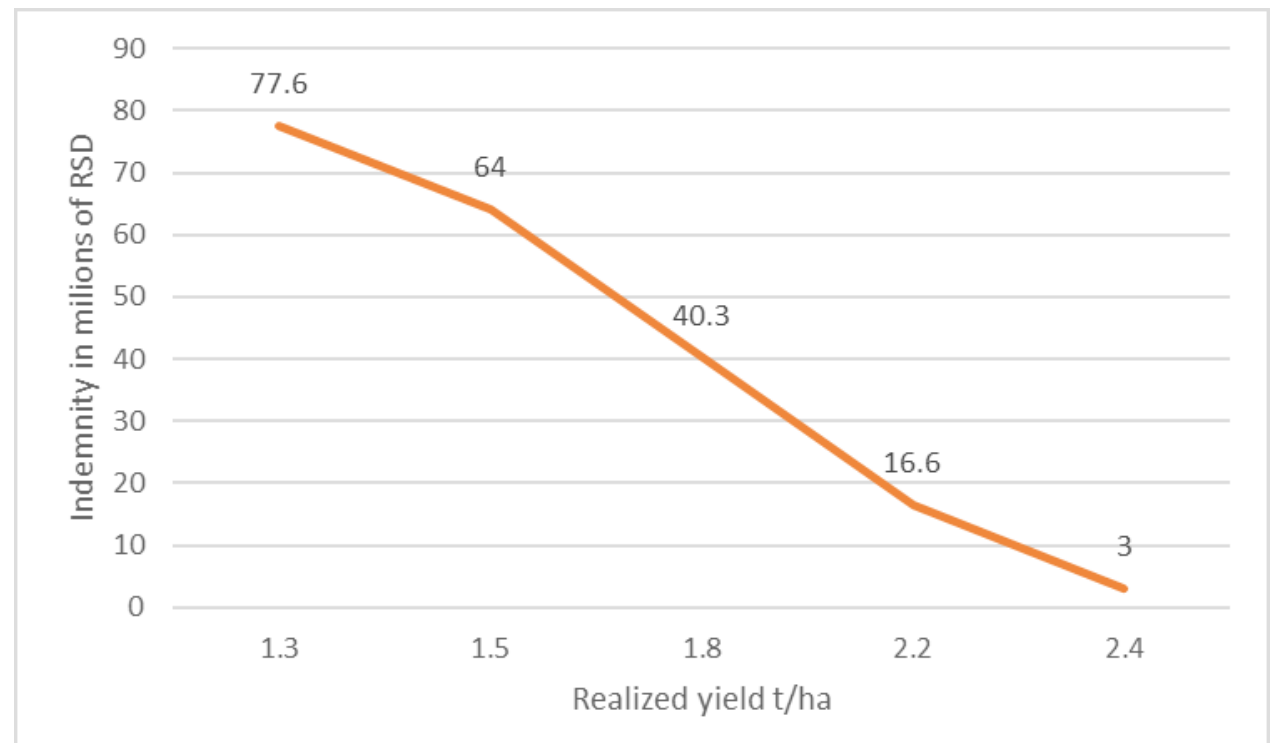

Source: Authors

Analysing the sources of positive law, it was determined that in our country this area is not regulated by law. On the other hand, it has been established that there are no autonomous sources of law in this area either. It was found that insurance companies do not offer this form of crop insurance. It has been determined that this form of insurance belongs to the group of non-compulsory insurances and that the state does not provide support for this type of insurance within its incentive measures.

In legal terms, there are two relationships here. The first relationship is between the municipality, the insured and the insurance organization. The second relationship is between the municipality and sunflower producer. By the means of regulation, states are trying to replace or supplement those market mechanisms that do not fulfil their role satisfactorily (Lakićević et al., 2013). 
The first relationship is double-sided, while the relationship of the municipality and agricultural producers could be classified into the category of insurance in favour of third parties in which this third party has no obligation towards the insured. Agricultural producers would be beneficiaries of indemnity if the insured event occurs, or if the regional yield is less than $2,445 \mathrm{~kg} / \mathrm{ha}$. And the other relationship would become obligatory if the agricultural producers would undertake a contractual obligation to compensate the municipality for part or whole premium. However, in our law, this insurance category was not in use, and not all legal repercussions of this work are known. In particular, the position of local self-government regarding the possibility of concluding insurance in favour of third parties could be analysed. Although it could be classified as a subsidy, there are some differences in comparison to the classical forms of subsidies. The special legal issue is how to treat income from farmers based on their participation in the payment of the premium in the terms of law and finance.

There are several reasons for not implementing the insurance contract by applying a regional index. The first reason is economic by its nature because most of our local selfgovernments do not have enough economic resources to secure crops in their territory in this way (Veselinović et al., 2014). Another reason is the lack of interest of insurance organizations for this type of insurance and this contract, as well as insufficient education of agricultural producers in Serbia regarding the characteristics of this contract. The third reason is inadequate legal education and the lack of comparative practice in this area. In order to examine the possible elements of the insurance contract using a regional index, the following example is given (Table 3):

Table 3. An example of a sunflower insurance contract using a regional index

\begin{tabular}{|c|c|}
\hline \multicolumn{2}{|c|}{ Insurance contract based on a regional index } \\
\hline \multicolumn{2}{|c|}{ Contracting Parties } \\
\hline Kula Municipality & Name of Insurer \\
\hline $\begin{array}{l}\text { Kula, Street and Number, Serbia } \\
\text { (Insured) }\end{array}$ & $\begin{array}{l}\text { Novi Sad, Street and Number, Serbia } \\
\text { (Insurer) }\end{array}$ \\
\hline \multicolumn{2}{|c|}{ Article 1} \\
\hline \multicolumn{2}{|c|}{$\begin{array}{l}\text { The subject of this Contract is the payment of the monetary compensation of the Insurer to } \\
\text { the Insured, which refers to the regional yield on the sunflower line, which will be planted in } \\
2016 \text { in the Kula municipality, on a total area of } 1,993 \text { hectares on the parcels that are attached } \\
\text { to this contract. The basis for payment is the difference between the guaranteed (insured) } \\
\text { yield per hectare and the realized sunflower yield per hectare in } 2016 \text {, and according to the } \\
\text { sunflower price on the Product Exchange in Novi Sad on August } 20^{\text {th }}, 2016 \text {. }\end{array}$} \\
\hline \multicolumn{2}{|c|}{$\begin{array}{c}\text { Article } 2 . \\
\text { Guaranteed (insured) yield }\end{array}$} \\
\hline Guaranteed (insured) yield is 2,44 & \\
\hline
\end{tabular}




\section{Article 3.}

Insurance sum per hectare and total insurance sum (RSD)

Contract sunflower price per kilogram is $34.00 \mathrm{RSD}$.

Total insurance sum is $165,678,090.00 \mathrm{RSD}$.

\section{Article 4.}

Realized yield

The realized yield shall be determined considering the realized yield of sunflower per hectare and the total yield of sunflower on the total area, expressed in kilograms, on parcels referred to in Article 1 of this Contract. The commencement harvest date, taking into account the created conditions of grain maturity and weather conditions, is determined by the Insured, with the notification of the Insurer.

Sunflower yield is determined based on the measurement of yield at 10 referenced places, with the size of 1 ha, and an average yield on these plots is multiplied by the total number of hectares $(1,993)$ and thus results in an overall value of the yield.

Measurement will be done when harvesting sunflower seed, according to pre-agreed activities, and measurement will be carried out by a control organization authorized by both contracting parties. Both contracting parties have the right to supervise the work of the control organization.

\section{Article 5.}

Insurance premium

Insured pays to the Insurer premium in the amount of 3,824 RSD per hectare.

Total insurance premium amount is 7,621,192.00 RSD.

The premium is paid within the set deadlines as follows: (timely define the payment terms for the premium)

\section{Article 6.}

Compensation for the lower yield than the guaranteed (insured)

The Insurer is obliged to pay the Insured a reduction in the yield according to the application of the regional index for the reduction of the guaranteed (insured) yield referred to in Article 2 of this Contract. The Insurer is obliged to pay out the value corresponding to the difference between the guaranteed (insured) and the realized yield from the insurance. The Insurer for the realized loss pays the monetary amount to the Insured.

\section{Article 7.}

Participation of the Insured in the risk coverage

Insured participate with $10 \%$ in risk coverage. 


\section{Article 8 .}

Control of the application of agro-technical and other measures

The Insured is obliged to ensure that sunflower producers on the insured areas carry out agrotechnical measures at least at the realized level in the previous referenced period, and the presentation of these measures is attached to this Contract making an integral part of it. An authorized person of an insurance organization will exercise control over the application of agro-technical measures that may affect the yield of sunflower on the parcels referred to in Article 1 of this Contract.

\section{Article 9.}

\section{Dispute resolution}

An ad hoc arbitration shall be formed by the contracting parties in order to settle disputes relating to this Contract by each contracting party appointing one arbitrator, and the appointed arbitrators shall appoint a third arbitrator, and also the chairman of ad hoc arbitration. An ad hoc arbitration decision has the force of an executive court ruling. Ad hoc arbitration will apply the rules of the Foreign Trade Arbitration of the Serbian Chamber of Commerce.

Article 10.

Number of contract copies

The Contract is made in 4 (four) copies, 2 (two) for each contracting party.

Article 11.

Place and date of the contract conclusion

The Contract is entered in Novi Sad on December 17 $7^{\text {th }}, 2015$.

Insured

Signature
Insurer

Signature

Source: Authors

The insurance contract of crops and fruits by applying the regional index by its legal nature is sui generis (Carić et al., 2011). It also contains elements of the insurance contract of yield, insurance against weather conditions, but also from the price fluctuations on the market. For farmers, which would thus be insured, this would mean safety in terms of climate fluctuations, but also partly in terms of fluctuations in the agricultural product market, because it could be counted with a defined yield. In agricultural production, this can also mean the insurance of unforeseen plant diseases. Compared to the classic insurance contract, this means that this contract involves several risks in one (Veselinović, 2011). In this way, one premium includes insurance against several uncertain events, which is not a feature of classic insurance contracts.

\section{Conclusion}

Agricultural production, as one of the most important sectors of the economy, is faced with numerous production risks, whose specificity is conditioned upon their quality management. This is reflected in the direct dependence of the achieved results and 
weather conditions. In order to manage these specific risks, the best solution is offered by various insurance systems. One of the newer models is also insurance based on the achieved regional yield, whose use can greatly reduce significant damage that often affects certain regions. On the example of the analysed municipality, observing the sunflower, one of the most common crops, potential losses can be compensated in production in the form of a maximum payment of 40.3 million RSD, at the level of $85 \%$ coverage of the average yield. On the other hand, the insurance premium cost (3,824 RSD / ha) can be lower than in the conventional crop insurance system, as well as in indirect index insurance, which is certainly positive from the aspect of the limited financial power of the farmers.

With a clear strategy at the state level, and by establishing a legal framework and financial incentives, the analysed insurance model in Serbia could be successfully implemented, and thus insure many agricultural producers who perform their activities in climatically unstable regions. A comprehensive analysis of the legal aspects of this contract, with a comparative analysis, would contribute to its easier implementation in economic practice.

\section{Literature}

1. Belei, S. (2017). The diversification of the rural economy as a tool for levelling the inbalance of rural development, $2^{\text {nd }}$ Seminar "Tourism in function of development of the Republic of Serbia”, June 1-3, Vrnjacka Banja, 2017.

2. Bielza Maria, Stroblmair, J., \& Gallego, J. (2007). Agricultural Risk Management in Europe. $101^{\text {st }}$ EAAE Seminar „Management of Climate Risks in Agriculture”, July 5-6, Berlin, 2007.

3. Calanca, P. (2007). Climate change and drought occurrence in the Alpine region: how severe are becoming the extremes? In: Global and Planetary Change, Vol. 57, No. 1-2, Elsevier, Atlanta, United States of America.

4. Carić, S., Vitez, M., Raičević, V., \& Veselinović, J. (2011). Privredno pravo. Fakultet za ekonomiju i inženjerski menadžment, Novi Sad, Srbija.

5. Carter, M. R., Galarza, F., \& Boucher, S. (2007). Underwriting Area-based Yield Insurance to Eliminate 'Risk Rationing' and Crowd - in Credit Supply and Demand. International Conference on Rural Finance Research: Moving Results into Polices and Practice, 16-17, Rome.

6. Chambers, R. G., \& Quiggin, J. (2002). Optimal Producer Behavior in the Presence of Area-Yield Crop Insurance. American Journal of Agricultural Economics, 84(2), 320-334.

7. Deng, X., Barnett, B. J., Hoogenboom, G., Yu, Y., \& Garcia, A. (2008). Alternative Crop Insurance Indexes. Journal of Agricultural and Applied Economics, 40(1), 223-237.

8. Dismukes, R., Coble, K., Miller, C., \& O’Donoghue, E. (2013). The effects of area-based revenue protection on producers' choices of farm-level revenue insurance, Agricultural and Applied Economics Association 2013 Annual Meeting, Washington, DC. 
9. Ebneth, O.J. (2003). Mehrgefahrenversicherung als Risiko-Management-Instrument für die deutsche Landwirtschaft. Masterarbeit, Fakultät für Agrarwissenschaften, Göttingen

10.Fuhrer, J., Beniston, M., Fischelin, A., Frei, C., Goyette, S., Jasper, K., \& Pfister, C. (2006). Climate risks and their impact on agriculture and forests in Switzerland. In: Climatic Change, Vol. 79, No. 1-2, Dordrecht, The Netherlands.

11. Halcrow, H. G. (1949). Actuarial Structures for Crop Insurance. Journal of Farm Economics, 31, 418-443.

12. Hirschauer, N., \& Mußhoff, O. (2008). Risikomanagementinstrumente im Vergleich: Sollte man landwirtschaftliche Ernteversicherungen subventionieren? Gute alte Argumente in einem neuen Streit, Vortrag anlässlich der 48. Jahrestagung der GEWISOLA ,Risiken in der Agrar und Ernährungswirtschaft und Ihre Bewältigung“, 24.-26. September, Bonn

13. Jain, G., \& Foster, D. (2000). Come rain, come shine. In: Energy and Power Risk Management - Weather Risk Special Report, Vol. 5, No. 5, London, United Kingdom of Great Britain and Northern Ireland.

14. Lakićević, M., Milutinović S., Žarevac, M. (2013). Makroekonomski efekti regulacije i deregulacije, Menadžment u hotelijerstvu i turizmu (HiT Menadžment), 1(1), 91-99.

15. Marković, T., Ivanović, S., \& Todorović, S. (2013). Reduction in Revenue Volatility in Maize Production Applying the Indirect-Index Insurance. Economics of Agriculture, 60(3), 445-454.

16. Marković, T. (2013). Vremenski derivati i upravljanje rizikom u poljoprivredi, Univerzitet u Novom Sadu, Poljoprivredni fakultet, Novi Sad, Srbija.

17. Marković, T., Veselinović, J., \& Kokot, Ž. (2016). Reduction of Volatility Yield and Prices in Corn Production Using Revenue Insurance. Economics of Agriculture, 63(3), 959-972.

18. Miranda, M. J. (1991). Area-Yield Crop Insurance Reconsidered, American Journal of Agricultural Economics, 73, 233-242.

19. Prettenthaler, F., Strametz, Sandra, Töglhofer, C., \& Türk, A. (2006). Anpassungsstrategien gegen Trockenheit - Bewertung ökonomisch-finanzieller versus technischer Ansätze des Risikomanagements, Wegener Center Verlag, Graz.

20. Schlieper, P. (1997). Ertragsausfallversicherung und Intensität pflanzlicher Produktion, Wiesbaden

21. Skees, J. R., Black, J. R., \& Barnett, B. J. (1997). Designing and Rating an Area Yield Crop Insurance Contract, American Journal of Agricultural Economics, 79, 430-438.

22. The World Bank (2009). Index - based Crop Insurance in Senegal, Promoting Access to Agricultural Insurance for Small Farmers, Sustainable Development, Africa Region, Finance and Private Sector Development.

23. Veselinović J. (2011). Privredno pravo, Univerzitet u Novom Sadu, Poljoprivredni fakultet, Novi Sad, Srbija. 
24. Veselinović, J., Marković, T., \& Đukić, S. (2014). Analysis of Legal and Economic Aspects of Precipitation Weather Derivatives for Serbian Agricultural Sector. Economics of Agriculture, 61(4), 053-1067.

25. Wolf, T. (1998). Ernteversicherungssysteme als Risk-Management Instrument für den Landwirt und ihr Einsatz im Rahmen der US-Agrarpolitik, Masterarbeit, München-Weihenstephan, Deutschland.

26. www. http://webrzs.stat.gov.rs/WebSite/Public/ReportView.aspx

\title{
EKONOMSKI I PRAVNI ASPEKTI OSIGURANJA SUNCOKRETA KORIŠĆENJEM MODELA REGIONALNOG INDEKSA
}

\author{
Todor Marković ${ }^{5}$, Janko Veselinović ${ }^{6}, \check{Z ̌ e l j k o ~ K o k o t ~}^{7}$ \\ Sažetak
}

Primena indeksnog osiguranja u poljoprivredi postaje sve zastupljenija u poslednjih nekoliko godina, posebno u razvijenim zemljama. Indeksno osiguranje useva i plodova bazirano je na podacima vezanim za određenu administrativnu jedinicu ili region. Regionalni indeks predstavlja prosečan prinos ili prosečnu vrednost proizvodnje u nekom regionu koji predstavlja osnovu za izračunavanje premije i naknade iz osiguranja. Na primeru proizvodnje suncokreta, kao jednog od najzastupljenijih useva u regionu opštine Kula, autori prikazuju metodologiju primene analiziranog sistema osiguranja. Kao osnovne prednosti ovog modela osiguranja mogu se navesti činjenice da ne postoji potreba za procenom štete, kao i drastično smanjenje moral-hazarda. Navedeni model osiguranja može predstavljati značajnu alternativu klasičnom osiguranju i njegova primena bi trebala da rezultira povećanjem broja osiguranika i osiguranih površina. Prethodno je potrebno otkloniti potencijalne pravne nedoumice oko primene ovog modela osiguranja u Srbiji i preciznije definisati neke pravne institute u ovoj oblasti.

Ključne reči: osiguranje, regionalni indeks, suncokret, procena štete, moral-hazard

5 Dr Todor Marković, vanredni profesor, Univerzitet Novi Sad, Poljoprivredni fakultet, Departman za ekonomiku poljoprivrede i sociologiju sela, Trg Dositeja Obradovića 8, 21000 Novi Sad, Srbija, Tel.: +381 2148534 19, E-mail: todor.markovic@polj.edu.rs

6 Dr Janko Veselinović, vanredni profesor, Univerzitet Novi Sad, Poljoprivredni fakultet, Departman za ekonomiku poljoprivrede i sociologiju sela, Trg Dositeja Obradovića 8, 21000 Novi Sad, Srbija, Tel.: +381 2148533 78, E-mail: veselinovic.janko@gmail.com

7 M.Sc Željko Kokot, doktorand, Univerzitet Novi Sad, Poljoprivredni fakultet, Departman za ekonomiku poljoprivrede i sociologiju sela, Trg Dositeja Obradovića 8, 21000 Novi Sad, Srbija, Tel: +381 6430552 92, E-mail: zeljko.kokot5@gmail.com 